\title{
Zinc Finger Protein ZFPM2
}

National Cancer Institute

\section{Source}

National Cancer Institute. Zinc Finger Protein ZFPM2. NCI Thesaurus. Code C102766.

Zinc finger protein ZFPM2 (1151 aa, $128 \mathrm{kDa}$ ) is encoded by the human ZFPM2 gene.

This protein plays a role in DNA binding, transcriptional regulation and cardiac development. 